\title{
A CASE OF DIVERTICULITIS OF THE VERMIFORM APPENDIX
}

\author{
By W. K. Douglas, F.R.C.S. . \\ Surgical Registrar, Lancaster Royal Infirmary
}

In view of the rarity of this condition, it seems worth recording an example.

\section{Case Report}

A man, aged 75, was admitted to the Royal Lancaster Infirmary on September 7, I95 I, with a history of pain which had commenced in the right iliac fossa three days previously. The pain later radiated to the hypogastrium and round to the posterior aspect of the right ilium. There was no associated nausea or vomiting but the patient complained of flatulence and abdominal distension. He had been constipated for three days and his appetite poor during that time. He gave no previous history of similar attacks of pain. On examination the temperature was $10 I^{\circ} \mathrm{F}$. and pulse 84. Examination of the abdomen revealed tenderness in the right iliac fossa with some muscle guarding. There was no mass palpable and rectal examination proved negative. A diagnosis of acute appendicitis was made and an immediate operation carried out. A grid-iron incision was made, and the appendix was found lying in a lateral caecal position. There was a small amount of purulent free fluid. The appendix appeared to be acutely inflamed and was wrapped in a fold of omentum. An appendectomy was performed and the wound closed.

\section{Macroscopic Examination}

The appendix was $9 \mathrm{~cm}$. long. The serous coat was reddened and, arising from the convex aspect of the appendix at about its middle, was a solitary diverticulum whose wall seemed to consist only of mucous membrane, purplish in colour. A longitudinal section was made. A small amount of purulent fluid was expelled from the lumen of the diverticulum; the lumen of the appendix was uniform and patent along its whole length. It was interesting to note the sharp line of demarcation between the purplish membrane of the diverti- culum and the normal colour of the mucous $\mathrm{s}^{\circ}$ membrane of the appendix. The wall of the appendix was thickened beyond its normal limitsir and muscle fibres could be clearly seen inter $\frac{\hat{A}}{\mathrm{~N}}$ spersed with fibrous tissue strands. The con-o tinuity of the wall was broken at the site of the diverticulum. On the concave aspect the mesen-O tery of the appendix contained an increased $\stackrel{O}{O}$ amount of fibro-fatty tissue. Microscopic ex-음 amination of the specimen was not made.

The patient made an uneventful recovery a $\frac{0}{40} \overrightarrow{0}$ was discharged on September 17, 195 I.

\section{Discussion}

In his review of cases seen at King's Hospital, London, between the years 1927 and 1934, Harold $\stackrel{\circ}{\AA}$ Edwards puts the incidence at less than 0.93 per $\Rightarrow$ cent. Other authorities give an even lower figure. $\frac{3}{3}$ McCarty and McGarth found 17 cases in 5,000 specimens, an incidence of 0.34 per cent. Moscho-券 witz found four cases in 1,500 specimens, an incidence of 0.26 per cent. Harold Edwards found 3 . that the diverticula were invariably associated with inflammation of the appendix, though the diverticula themselves were uncommonly affected. They $ᄋ$ are usually multiple and may be complete or in- 3 complete. If complete, they are true herniations of the mucosa through the muscle coat of the appendix. They are usually situated on the concave aspect of the appendix and the most striking feature is the thickening of the muscle coat with? the muscle replaced in certain parts by fibrous $N$ tissue. It is through these parts of the muscle coat, weakened by the presence of the fibrous tissue that the diverticula are formed. The lumeno is usually distorted and pockets are formed which $\frac{\varnothing}{\Phi}$ later, by means of pressure atrophy, will become $\stackrel{\oplus}{+}$ the complete diverticula. The appendix is nearly 0 always affected by previous attacks of inflammation thus resulting in the thickening of the ap- $\stackrel{\Phi}{\Phi}$ 
pendix wall. An appendix inflamed de novo is rarely associated with diverticula. The inflammation presenting may be acute or chronic.

With the knowledge of the pathology the causation of these diverticula can be determined. It is evident that there are three factors involved. Firstly, the muscle in the thickened wall of the inflamed appendix contains lymphoid tissue, later granulation tissue appears, invades the submucous coat and finally the muscle, leaving a weakened scar. Secondly, because of the inflammation, spasm of the muscle fibres becomes a factor; first the longitudinal fibres and then the circular fibres contract and the mucous membrane herniates through. Third and lastly, there is obstruction of the lumen with irregular distension, thus resulting in the formation of pockets.

Thus it can be seen that the case presented differs in many respects from the common descrip- tion. The diverticulum was solitary, it presented on the convex aspect of the appendix and far from being unaffected by the associated in- $\varrho$ flammation of the appendix was involved in an infarction process. The lumen was uniform in length, with none of the distortion so characteristically seen in other cases. Finally, the thickening of the meso-appendix was less than one expects to see in such cases.

My thanks are due to Mr. W. Magauran for permission to publish this case, and to both him and Mr. E. P. Hall-Drake for their kindly criticism.

\section{BIBLIOGRAPHY}

EDWARDS, H. (1934), Brit. F. Surg., 85.

MCCARTY, H. C., and MCGRATH, B. T. (I911), Surg. Gynecol. Obst., 12, 211 .

MOSCHOWITZ, E. (1916), Annals of Surgery, t3, 697.

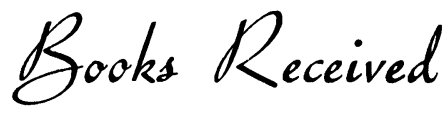

The Editorial Board acknowledge with thanks receipt of the following volumes. $\quad A$ selection from these will be made for review.

'Diseases of the Heart and Circulation.' By Albert A. Fitzgerald Peel, M.A., D.M., F.R.F.P.S. (G.). 2nd Edition. Pp. xxiii +472 with 91 illustrations. London: Geoffrey Cumberlege, Oxford University Press. 1952. 35 s.

'A Textbook on the Nursing and Diseases of Sick Children for Nurses.' Edited by Alan Moncrieffe, M.D., F.R.C.P. 5th Edition. Pp. xiv + 770, with I6I illustrations. London: H. K. Lewis \& Co. Ltd. 1952. 37s. 6d.

' S.F.A. Catalogue of Medical Films.' Pp. xvi + r95. London: Harvey \& Blythe. 1952. I5s.

' Topics in Physical Chemistry.' By W. Mansfield Clark, Ph.D., Sc.D. and Edition. Pp. xviii + 777, with 176 illustrations. London: Baillière, Tindall \& Cox. r952. 76s. 6d.

'The Rhesus Factor.' By G. Fulton Roberts, M.A., M.D. 3rd Edition. Pp. vii + 90. London: William Heinemann. 1952. 5s.

' Ciba Foundation-Colloquia on Endrocrinology. Vol. I.' General Editor for the Ciba Foundation, G. E. W. Wolstenholme, O.B.E., M.A., M.B.,
B.Ch., assisted by Margaret P. Cameron, M.A., A.B.L.S. Pp. $\mathrm{xx}+3 \mathrm{I}$, with 48 illustrations. London: J. \& A. Churchill, Ltd. 1952. 30 .

'Synopsis of Tropical Medicine.' By Sir Philip Manson-Bahr, C.M.G., D.S.O., M.A., M.D. D.T.M. \& H., F.R.C.P. 2nd Edition. Pp. xiii + 248, with 7 illustrations. London: Cassell \& Co. Ltd. I952. I5s.

'Chemotherapy and the Antibiotic Drugs.' Pp. 68. London: Fellowship of Postgraduate Medicine. N.d. 5 s.

'Edinburgh Postgraduate Lectures in Medicine. Vol. 5.' Pp. xi + 518, illustrated. Edinburgh: Oliver \& Boyd, Ltd. I952. 2 rs.

' History of the Royal Medical Society. 17371937.' By James Gray, M.A., F.R.S.E. Pp. xi + 355, with 7 illustrations. Edinburgh: Edinburgh University Press. 1952. 42s.

'Principles and Practice of Aviation Medicine.' By H. G. Armstrong, M.D., F.A.C.P. 3rd Edition. Pp. $x+475$, with 95 illustrations. London: Baillière, Tindall \& Cox. 1952. 57s. 6d. 